\title{
Study of BOD and COD Removal in Batik Wastewater using Scirpus grossus and Iris pseudacorus with Intermittent Exposure System
}

\author{
Bieby Voijant Tangahu', Dwi Agustiang Ningsih', Setyo Budi Kurniawann², \\ Muhammad Fauzul Imron ${ }^{3}$
}

1 Department of Environmental Engineering, Faculty of Civil, Environmental and Geo Engineering, Institut Teknologi Sepuluh Nopember, Kampus ITS Sukolilo, Surabaya 60111, Indonesia

2 Politeknik Perkapalan Negeri Surabaya, Jalan Teknik Kimia, Kampus ITS Sukolilo, Surabaya 60111 Indonesia

3 Study Program of Environmental Engineering, Department of Biology, Faculty of Science and Technology, Universitas Airlangga, Kampus C UNAIR, Jalan Mulyorejo, Surabaya 60115, Indonesia

* Corresponding author's email: setyobudi.kurniawan@gmail.com

\begin{abstract}
Batik is one of ethnical cultures of Indonesia. The batik production has spread throughout Indonesia. One of the batik industry areas is located in Jetis, Sidoarjo, Indonesia. This industry has been operating for approximately 350 years without processing its wastewater. The batik wastewater contains several toxic compounds such as high $\mathrm{BOD}, \mathrm{COD}$ and color pigment. These compounds can be harmful for the environment if discharged directly to water bodies. Phyto-treatment might be a solution to overcome this problem. The use of Scirpus grossus and Iris pseudacorus with variations of waste irrigation system using the intermittent method showed a COD removal up to $89 \%$ and BOD removal up to $97 \%$. Mixed culture of S. grossus and I. pseudacorus showed a better removal than its single culture. The highest removal of BOD and COD was obtained in reactor with mixed culture plants under Flood/ Drain ratio of 2:1.
\end{abstract}

Keywords: Batik, F/D, I. pseudacorus, Mixed Culture, S.grossus.

\section{INTRODUCTION}

The batik wastewater mostly produced from the cloth coloring and drenching processes [Suprihatin, 2014]. The batik wastewater contains many compounds that could pollute the environment. The chemicals that often used in coloring process were acid color, base color, direct color, reactive color, naphthol color, and container color substance [Kurniawan et al., 2013]. The use of those substances causes the batik wastewater to contain high concentration of coloring substance, Biochemical Oxygen Demand (BOD), Chemical Oxygen Demand (COD) and some heavy metals [Rashidi et al., 2012]. One of the batik industries located in Jetis, Sidoarjo, Indonesia. This industry has been operating since 1675 [Watini, 2009].
Along this operation period, its wastewater was directly discharged to Jetis River through the nearest drainage channel [Satrya, 2015]. The wastewater was discharged directly without undergo any further processes.

Proper disposal of this wastewater needs to be carried out in order to prevent environmental pollution. Phyto-treatment provides a prospective green technology to treat this type of wastewater before being discharged to the water bodies [Tee et al., 2009; Purwanti et al., 2018]. Phytotreatment is considered to be cost effective, environmentally-friendly and having high removal efficiency. Phyto-treatment utilizes the plant metabolism to remove contaminants from wastewater [Tee et al., 2009]. Two well-known plant species, Scirpus grossus [Purwanti et al., 2018] and 
Iris pseudacorus [Stottmeister et al., 2003] were widely used as phyto-treatment agent.

$S$. grossus and I. pseudacorus are semiaquatic plants that have high survivability in high polluted environment [Stottmeister et al., 2003]. These plants can live well in nearly dry condition or highly saturated soil, making it suitable to be used under the intermittent system. The intermittent system is a periodical exposure of water that passing through plants living medium. In the case of wastewater used in the intermittent system, the dry period gives time for plant to recover before another exposure. This system interacted the plants and wastewater through dry and flood cycle (F/D). This interaction provides a better reduction-oxidation condition; thus, organic compound removal in wastewater can be increased [Jia et al., 2010].

The previous studies for the batik wastewater mostly discussed its heavy metal removal [Suprihatin, 2014; Purwanti et al., 2017]. Since the intermittent system provides a better redox condition, conducting a study on its organic content removal was relevant. Variations of single and mixed plants were used in this research under F/D of 2:1 and 1:2. These variations were used to understand the mechanism of organic content (BOD and COD) removal in the batik wastewater by selected plants (S. grossus and I. pseudacorus) under various intermittent exposure system. The result of this research may highlight on the effect of intermittent system to the removal of BOD and COD in wastewater using $S$. grossus and I. pseudacorus.

\section{MATERIALS AND METHOD}

This study was conducted in laboratory scale. Two species of plants, S. grossus and I. pseudacorus, were taken from laboratory culture. Intermittent exposure was chosen based on the discharge period of the batik wastewater under actual conditions. Flood and drain (F/D) ratio of 2:1 and 1:2 were chosen as the intermittent period [Jia et al., 2010]. The batik wastewater was taken from a local batik industry located in Jetis, Sidoarjo, East Java, Indonesia.

\section{a) Propagation of plants}

Propagation was carried out to reproduce plant which would be needed for the study. Propagation was conducted in $35 \mathrm{~L}$ of plastic reactor filled with garden soil. The second generation of plants with the same age and height were used in every research stage to ensure the same initial conditions between tested plants [Al-Baldawi et al., 2015].

\section{b) Acclimatization of plants}

Plant acclimatization was conducted to adapt the tested plants 0 to the conditions and medium which was used in the Range Finding Test (RFT) and phyto-treatment stage. This step took 7 days of plants to live in gravel medium watered by tap water [Purwanti et al., 2015]. Plant acclimatization was conducted in $35 \mathrm{~L}$ of plastic reactor. In this stage, plants condition was expected to grow healthily (not withering). The healthy plants from this stage were used in RFT and phyto-treatment stage.

c) Range Finding Test (RFT) of Batik wastewater RFT was conducted to determine the maximum concentration of the batik wastewater where the tested plants can still live well. This step was carried out by making various concentrations of the batik wastewater by diluting it with tap water [Purwanti et al., 2018]. Variation of concentrations in this stage were $0 \%$ (control), $10 \%, 20 \%$, $30 \%, 40 \%$, and $50 \%$ of the batik wastewater. This stage was conducted for 7 days to analyze the plant growth. A total of 4 plants were used for each concentration. Plant growth was the main parameter to be analyzed in this step to determine the maximum concentration to be used in the phyto-treatment step.

d) Phyto-treatment of the batik wastewater

Phyto-treatment of the batik wastewater was carried out for the concentration that was obtained from RFT. A 50L plastic reactors were used in this stage. A total of 8 plants were used for every reactor on this stage. Single and mixed culture of S. grossus and I. pseudacorus were used to determine the ability of BOD and COD removal under different culture combination. A 50\%:50\% number of plants were used in mixed culture [Tangahu et al., 2011]. Flooding and draining cycles were conducted by drainage system under reactors. Flooding was carried out by filling reactors with wastewater while closing the drainage valve. Draining performed by opening the drainage valve until reactor was completely dry. Intermittent cycle of 1:2 and 2:1 were chosen in this stage [Jia et al., 2010]. Each ratio represents the day of flood and day of drain inside reactors. This stage was carried out for 18 days; thus, each 
reactor would run into 6 cycles of F/D. The feeding of batik wastewater for every cycle of $\mathrm{F} / \mathrm{D}$ was determined from RFT. The RFT concentration result was divided into 6 feeding cycles that made the total concentration in every reactor during test period was equal to RFT concentration. The concentration of BOD and COD were tested every day as the main parameter in this stage.

\section{RESULT AND DISCUSSION}

a) Batik Wastewater Characteristic

Initial characterization of the batik wastewater was conducted to color the wastewater taken from the study area. The batik wastewater characteristics are shown in Table 1.

Table 1 indicates that the values of $\mathrm{pH}$, TSS, BOD, COD, total ammonia, grease and fat were highly exceeding the standard. The BOD value was measured up to $2,710 \mathrm{mg} / \mathrm{L}$ and COD value up to $3,855 \mathrm{mg} / \mathrm{L}$. These concentrations were used as a reference in determining the RFT concentration.

\section{b) Range Finding Test (RFT)}

From the 7 days observation, it could be seen that Scirpus grossus could live well in the concentration of $20 \%$, which was equivalent to 770.92 $\mathrm{mg} / \mathrm{L} \mathrm{COD}$ and $542 \mathrm{mg} / \mathrm{L}$ BOD. This indicated by zero number of dead plants after 7 days of exposure. In the concentration of $30 \%$ to $50 \%$, Scirpus grossus could not grow well, indicated by the withering and yellowing leaves of tested plants after 7 days of exposure [Purwanti et al., 2018]. Iris pseudacorus could grow well in concentration of $30 \%$, which was equivalent to 1156.4 $\mathrm{mg} / \mathrm{L} \mathrm{COD}$ and $813 \mathrm{mg} / \mathrm{L}$ BOD. All tested plants experienced withering and yellowing of leaves in concentration of $40 \%$ to $50 \%$. From this result, $20 \%$, of the batik wastewater which was equivalent to $770.92 \mathrm{mg} / \mathrm{L} \mathrm{COD}$ and $542 \mathrm{mg} / \mathrm{L}$ BOD was used as phyto-treatment concentration for Scirpus grossus while $30 \%$ of batik wastewater which was equivalent to $1156.4 \mathrm{mg} / \mathrm{L} \mathrm{COD}$ and $813 \mathrm{mg} / \mathrm{L}$ BOD was used for Iris pseudacorus.

c) Phytotreatment of Batik Wastewater

The results of BOD and COD removal for every research variation were shown in Figures 1 to 4. Figures 1 to 4 show that the removal efficiency for each variation, either single or mixed culture and F/D 1:2 or 2:1, tended to increase and were higher than the control in the observation period.
Table 1. Initial characterization of the batik wastewater

\begin{tabular}{|c|l|c|c|c|}
\hline No & \multicolumn{1}{|c|}{ Parameter } & Unit & Result & Standard \\
\hline 1 & $\mathrm{pH}$ & - & 10.8 & $6-9$ \\
\hline 2 & $\mathrm{TSS}$ & $\mathrm{mg} / \mathrm{L}$ & 1,180 & 50 \\
\hline 3 & $\mathrm{COD}$ & $\mathrm{mg} / \mathrm{L} \mathrm{O}_{2}$ & 3,855 & 150 \\
\hline 4 & $\mathrm{BOD}$ & $\mathrm{mg} / \mathrm{L} \mathrm{O}_{2}$ & 2,710 & 60 \\
\hline 5 & Sulfide & $\mathrm{mg} / \mathrm{L} \mathrm{H}_{2} \mathrm{~S}$ & 0.00 & 0,3 \\
\hline 6 & Total ammonia & $\mathrm{mg} / \mathrm{L} \mathrm{NH}_{2}-\mathrm{N}$ & 180.92 & 8 \\
\hline 7 & Total chromium & $\mathrm{mg} / \mathrm{L} \mathrm{Cr}^{-1}$ & 0.45 & 1 \\
\hline 8 & Grease and fat & $\mathrm{mg} / \mathrm{L}$ & 70 & 3 \\
\hline 9 & Phenol & $\mathrm{mg} / \mathrm{L}$ & 0 & 0.5 \\
\hline
\end{tabular}

Note: East Java Governor's Act on Standard of Textile Industry Wastewater No. 72, 2013

The highest removal was occurred on $11^{\text {th }}$ day for reactor F/D 1:2 and $12^{\text {th }}$ day for reactor F/D 2:1 (each in the $4^{\text {th }}$ waste feeding). In the single culture reactor, Scirpus grossus showed a COD removal up to $83 \%$ in F/D 1:2 exposure and $82 \%$ in F/D 2:1 exposure. Single culture of Iris pseudacorus showed a COD removal value up to $82 \%$ in F/D 1:2 exposure and $83 \%$ in F/D 2:1 exposure. Mixed culture reactor showed a COD removal value up to $85 \%$ in F/D 1:2 exposure and $89 \%$ in F/D 2:1 exposure. For the BOD parameter, Scirpus grossus showed a removal up to $85 \%$ in F/D 1:2 exposure and 90\% in F/D 2:1 exposure. Iris pseudacorus showed a BOD removal up to $91 \%$ in F/D 1:2 exposure and $95 \%$ in F/D 2:1 exposure. Mixed culture reactor showed a BOD removal value up to $94 \%$ in F/D 1:2 exposure and 97\% in F/D 2:1 exposure. This result indicates that highest removal value was found in mixed culture reactor with F/D 2:1. This was caused by the inter-species competition in nutrition fulfilling during phyto-treatment period [Novotny and Olem, 1994]. The inter-species competition

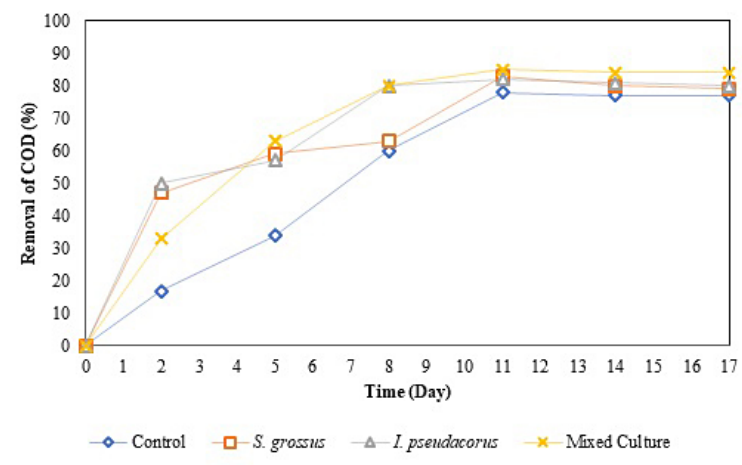

Figure 1. COD removal under F/D 1:2 system 


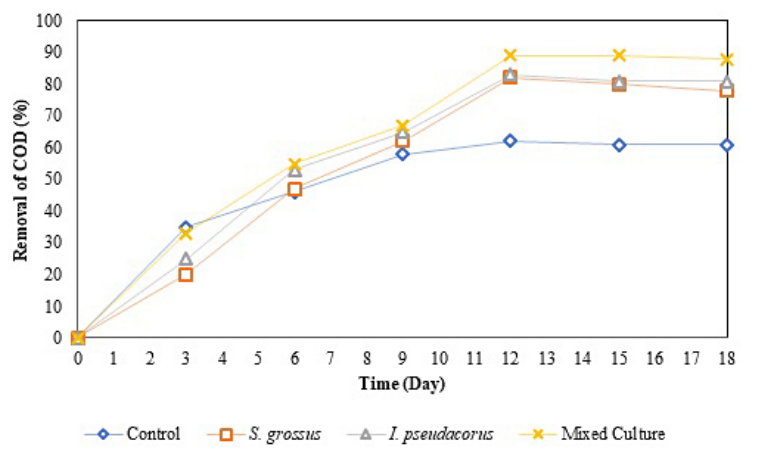

Figure 2. COD removal under F/D 2:1 system

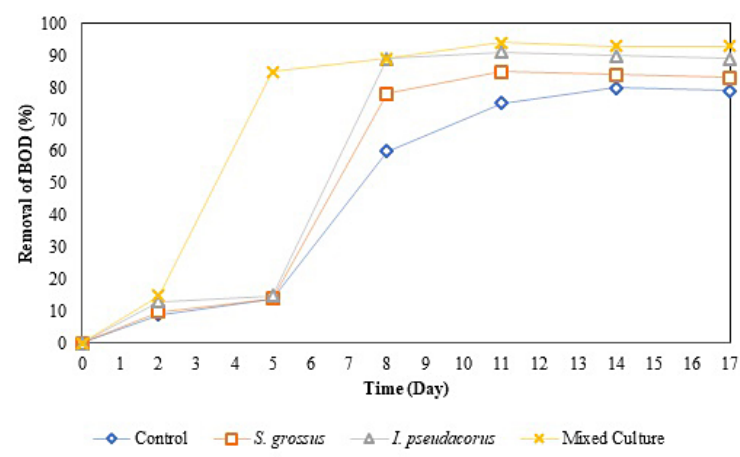

Figure 3. BOD removal under F/D 1:2 system

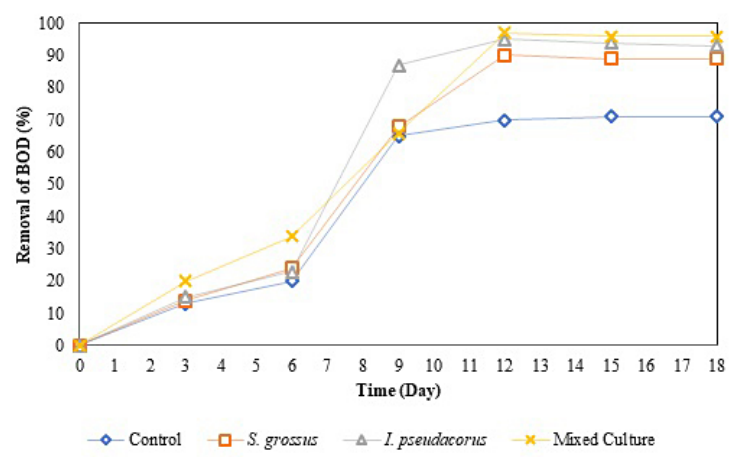

Figure 4. BOD removal under F/D 2:1 system

triggered the tested plants to take upmore nutrient, thus causing the COD concentration to decrease to a greater degree than in the single culture. The increasing of COD removal value to be higher for each day was caused by the growth of microorganism in the root zone of tested plants [Tangahu et al., 2011]. The phyto-treatment working principle was utilizing the symbiosis between plants and microorganism in the media around the root system [Hayati, 1992].

Highest removal increase was found in the F/D 2:1. The application of 2 days flooding cycle gave longer waste exposure duration towards treatment system compared to 1 day flooding cycle. The decrease of COD and BOD was affected greatly by the organism activity and the plant capability in absorbing nutrition; thus, longer exposure duration meant greater eliminated organic matter through biodegradation mechanism [Dhamayanthie, 2000]. The organic matter contained in the batik wastewater can be a nutrition source for microbes which would then turn into simpler substance. Longer exposure duration causes microorganism to degrade organic matter more effectively along with plant organic substance uptake as its nutrition. The intermittent exposure system with flood and drain cycle gave significant impact to the removal of BOD and COD $(\mathrm{P}<0.05)$ while plant types and its culture combination did not $(\mathrm{P}>0.05)$. The plant capability for absorbing organic matter increased along time because drying cycle gave it chance to recover its capability for absorbing contaminants [Jia et al., 2010].

\section{CONCLUSION}

The highest BOD and COD in the batik wastewater removal occurred in the mixed culture of S. grossus and I. pseudacorus reactor under F/D $2: 1$ system with a removal value up to $97 \%$ for BOD and $89 \%$ for COD. The utilization of mixed culture plants can increase the removal efficiency up to $7 \%$. The intermittent system had a significant impact on the removal of organic matter in Batik wastewater. The highest removal was obtained under F/D 2:1 system caused by a longer interaction between a plant and wastewater.

\section{REFERENCES}

1. Al-Baldawi, I.A.W., Abdullah, S.R.S., Suja, F., Anuar, N., and Idris, M. 2013. A phytotoxicity test of bulrush (Scirpus grossus) grown with diesel contamination in a free-flow reed bed system. Journal of Hazardous Materials, 252(1), 64-69.

2. Dhamayanthie, I., 2000, Pengolahan Limbah Cair Industri Textile dengan Proses Anaerob, Master Thesis, Chemical Engineering, ITB, Bandung, Indonesia.

3. Hayati, N. 1992. Kemampuan eceng gondok dalam mengubah sifat fisik kimia limbah cair pabrik pupuk urea dan asam formiat. Master Thesis, Biology, ITB, Bandung, Indonesia. 
4. Jia, W., Zhang, J., Wu, J., Xie, H., and Zhang, B. 2010. Effect of Intermittent Operation on Contaminant Removal and Plant Growth in Vertical Flow Constructed Wetlands: A Microcosm Experiment. Desalination, 262 (1), 202-208.

5. Kurniawan, M.W., Purwanto, P., dan Sudarso, S. 2013. Stratergi Pengelolaan Air Limbah Sentra UMKM Batik yang Berkelanjutan di Kabupaten Sukoharjo . Jurnal Ilmu Lingkungan, 11(2), 62-72.

6. Novoty, V. and Olem, H. 1993. Water Quality: Prevention, Identification and Management of Difuse Pollution. Van Nostrand Reinhold, New York.

7. Purwanti, I.F., Kurniawan, S.B., Tangahu, B.V., and Rahayu, N.M. Bioremediation of Trivalent Chromium in Soil Using Bacteria. International Journal of Applied Engineering Research, 12(20), 9346-9350.

8. Purwanti, I.F., Rozaimah, S.R.S., Hamzah, A., Idris, M., Basri, H., Mukhlisin, M. and Latif, M.T. Biodegradation of Diesel by Bacteria isolated from Scirpus mucronatus rhizosphere in Diesel-Contaminated San. Advance Science Letters, 21(2), 140-143.

9. Purwanti, I.F., Simamora, D., and Kurniawan, S.B. Toxicity Test of Tempe Industrial Wastewater on Cyperus rotundus and Scirpus grossus. International Journal of Civil Engineering and Technology, 9(4), 1162-1172.

10. Rashidi, H.R., Sulaiman, N.N.M., and Hashim, N.A. 2012. Batik Industry Synthetic Wastewa- ter Treatment using Nanofiltration Membrane. Proceedia Engineering, 44, 2010-2012

11. Satrya, R.W. 2015. Sejarah Industrialisasi Batik Di Kampung Batik Jetis Sidoarjo Tahun 1970-2013. Journal Pendidikan Sejarah, 3(3), 480-486.

12. Stottmeister U., WieBner, A., Kuschk, P., Kappelmeyer, U., Kastner, M., Bederski, O., Miiller, R.A., and Moormann, H. 2003. Effects of Plants and Microorganisms in Constructed Wetlands for Wastewater Treatment. Biotech. Advances, 22, 93-117.

13. Suprihatin, H. 2014. Kandungan Organik Limbah Cair Industri Batik Jetis Sidoarjo Dan Alternatif Pengolahannya. Bachelor Thesis, Institut Teknologi Pembangunan, Surabaya, Indonesia.

14. Tangahu, B.V., Abdullah, S.R.S., Basri, H., Idris, M., Anuar, N., and Mukhlisin, M. A Review on Heavy Metal (As, $\mathrm{Pb}$ and $\mathrm{Hg}$ ) Uptake by Plants Through Phytoremediation. International Journal of Chemical Engineering, 2011(2011).

15. Tee, H.C., Seng, C.E., Noor, A. Md, and Lim, P.E. 2009. Performance comparison of constructed wetlands with gravel- and rice husk-based media for phenol and nitrogen removal. Science of the Total Environment, 407, 3563-3571.

16. Watini. 2009. Pengaruh Waktu Kontak Eceng Gondok (Eichornia crassipes) terhadap Penurunan Kadar Cd dan Cr Pada Air Limbah Industri Batik (Home Industry Batik Di Desa Sokaraja Lor). Bachelor Thesis, Universitas Jenderal Soedirman, Purwokerto, Indonesia. 